\title{
Internal quality of commercial eggs stored under conditions that simulate storage from laying to consumption
}

\author{
R.A. Souza ${ }^{1,2}$, J.L.M. Mello" ${ }^{1 \#}$, F.B. Ferrari ${ }^{1}$, A. Giampietro-Ganeco ${ }^{1}$, P.A. Souza ${ }^{1}$, H. Borba ${ }^{1}$ \& \\ C.C. Pizzolante ${ }^{1}$ \\ ${ }^{1}$ São Paulo State University (UNESP), Department of Technology, Jaboticabal, São Paulo, Brazil \\ ${ }^{2}$ Institute of Animal Science and Pastures - IZ, APTA. Nova Odessa, São Paulo, Brazil
}

(Submitted 28 May 2109, Accepted 4 September 2019; Published 6 January 2021)

\author{
Copyright resides with the authors in terms of the Creative Commons Attribution 4.0 South African Licence. \\ See: http://creativecommons.org/licenses/by/4.0/za \\ Condition of use: The user may copy, distribute, transmit and adapt the work, but must recognise the authors and the South African \\ Journal of Animal Science.
}

\begin{abstract}
This study evaluated the effects on the internal quality of eggs of various storage environments through which eggs may pass between being laid and being consumed. Commercial eggs $(N=648)$ from Dekalb White hens were used. Treatments consisted of T1: 28 days at $4{ }^{\circ} \mathrm{C}$; T2: 28 days at $20{ }^{\circ} \mathrm{C}$; T3: 7 days at room temperature $\left(27{ }^{\circ} \mathrm{C} \pm 2{ }^{\circ} \mathrm{C}\right.$ ) (humidity $55 \%$ ) and 21 days at $4{ }^{\circ} \mathrm{C}$; T4: 7 days at room temperature and 21 days at $20^{\circ} \mathrm{C}$; T5: 14 days at room temperature and 14 days at $4{ }^{\circ} \mathrm{C}$; T6: 14 days at room temperature and 14 days at $20^{\circ} \mathrm{C}$; T7: 21 days at room temperature and 7 days at $4{ }^{\circ} \mathrm{C}$; T8: 21 days at room temperature and 7 days at $20^{\circ} \mathrm{C}$; and T9: 28 days at room temperature. The characteristics that were evaluated consisted of Haugh unit $(\mathrm{HU})$, yolk index $(\mathrm{YI})$, colour $\left(\mathrm{L}^{*}, \mathrm{a}^{*}\right.$ and $\left.\mathrm{b}^{*}\right)$, albumen $\mathrm{pH}$, yolk $\mathrm{pH}$ and lipid oxidation. Eggs stored 28 days were darker $\left(\mathrm{L}^{*}\right)$, and had greater yolk $\mathrm{pH}$ and lipid oxidation than fresh eggs. Eggs stored under T1 and T3 conditions had greater $\mathrm{HU}$ and $\mathrm{YI}$ than eggs stored in the other environments. The albumin $\mathrm{pH}$ of eggs stored at room temperature (T9) was highest of the treatments. Yellowness was increased in eggs stored under T4, T6, T8, and T9 conditions. Eggs should be stored under refrigeration as this promotes maintenance of internal quality and mitigates negative effects of previous storage conditions.
\end{abstract}

Keywords: fresh eggs, Haugh unit, laying hens, oxidation, storage, yolk index

\#Corresponding author: julianalolli@gmail.com

\section{Introduction}

Brazilian production of commercial eggs has increased by $30 \%$ over the last seven years, with 49 billion units produced in 2019. Consumption increased by $27 \%$ in the same period, and reached 230 eggs per capita per year (ABPA, 2020). Eggs are known traditionally as one of the most complete foods. They are an important source of fat, carbohydrates, vitamins, minerals and protein in particular, and can contribute to food security in resource-poor settings (lannotti et al., 2014). Eggs are highly perishable and start to deteriorate soon after laying (Akyurek \& Okur, 2009). Albumen quality is an important indicator of an egg's freshness, and is important to the egg processing industry (Jin et al., 2011).

Because of market demand and the growth of the poultry industry, sanitary technologies and alternative systems of storage have enhanced product quality, ensured consumer satisfaction and provided economic returns to the production sector (Scatolini-Silva, 2010). Because eggs are perishable, with various physical and chemical changes occurring inside the egg during the storage period (Tabidi, 2011), the way in which they are stored is important. Brazilian Resolution 35, 17 June 2009 (Brazil, 2009) states that packages containing eggs should recommend their storage under refrigeration, but this resolution is not mandatory

Eggs that are packaged improperly or stored at high temperatures and low humidity suffer accelerated biochemical changes to their albumin, making them prone to contamination by pathogens, which reduces their shelf life. This deterioration in quality is associated mainly with the loss of water and carbon dioxide during storage, with the rate of degradation being proportional to the ambient temperature (Leandro et al., 2005). Internal egg quality may be quantified with mathematical expressions that describe the differences between fresh and stored eggs and the changes that occur from storage conditions. Quality changes that are easily observable include those related to the ageing of the albumen and yolk and to the flattening of the yolk (Tabidi, 2011). Thus, the aim of this study was to evaluate the effects of storage under different 
environmental conditions on the internal quality of commercial eggs. Treatments were chosen to mimic the storage situations through which eggs may pass between the time they were laid and consumption.

\section{Material and Methods}

This study was developed at the Laboratory of Analyses of Animal Products of the School of Agricultural and Veterinary Sciences, Jaboticabal, São Paulo, Brazil). Briefly, the eggs $(N=648)$ were obtained from a commercial farm. Forty-one-week-old Dekalb White hens were housed in galvanized steel cages and fed a diet based on corn and soybean, which was balanced according to their nutritional requirements.

Eggs were taken from the first collection of the day and were transported to the laboratory on that same day. Eggs were randomly assigned to one of these treatments to simulate conditions such as household refrigerator storage, transport in a refrigerated vehicle, storage at room temperature in cities with a mild climate, storage at room temperature during the warmer seasons, and non-refrigerated transport. Thus, the treatments were as follows, T1: 28 days at $4{ }^{\circ} \mathrm{C}, \mathrm{T} 2: 28$ days at $20^{\circ} \mathrm{C}, \mathrm{T} 3: 7$ days at room temperature and for 21 days at $4{ }^{\circ} \mathrm{C}, \mathrm{T} 4: 7$ days at room temperature and 21 days at $20^{\circ} \mathrm{C}, \mathrm{T} 5: 14$ days at room temperature and for 14 days at $4{ }^{\circ} \mathrm{C}, \mathrm{T} 6: 14$ days at room temperature and for 14 days at $20^{\circ} \mathrm{C}, \mathrm{T} 7: 21$ days at room temperature and 7 days at $4{ }^{\circ} \mathrm{C}$, T8: 21 days at room temperature and 7 days at $20^{\circ} \mathrm{C}$, and T9: eggs stored at room temperature for 28 days. Eggs not stored (fresh eggs) were used as a control treatment.

Eggs were stored in a $250 \mathrm{~W}$ Eletrolab EL101 BOD incubator (Eletrolab, São Paulo, SP, Brazil) at 4 ${ }^{\circ} \mathrm{C}$ or $20^{\circ} \mathrm{C}$. The temperature of the uncontrolled environment ranged from $25^{\circ} \mathrm{C}$ to $29^{\circ} \mathrm{C}$ with an average relative humidity of $55 \%$. Haugh units and $\mathrm{pH}$ were used to measure albumen quality and colour $\left(\mathrm{L}^{*}, \mathrm{a}^{*}, \mathrm{~b}^{*}\right)$. $\mathrm{pH}$, yolk index and lipid oxidation were used to assess yolk quality.

Haugh units (Haugh, 1937) were measured as described by Card \& Nesheim (1978). Eggs were weighed individually on an analytical balance and broken on a special glass table. The height of dense albumen was measured in three positions with an Ames micrometer (model S-6428, Ames, Waltham, MA). Haugh units were calculated as:

$$
H U=100 \log \left(H+7.57-1.7 W^{0.37}\right)
$$

where $\mathrm{H}=$ the average height $(\mathrm{mm})$ of the dense albumin and $\mathrm{W}=$ the weight $(\mathrm{g})$ of the egg.

The $\mathrm{pH}$ of albumen and yolk were determined in samples that had been slightly homogenized with a glass rod, using a Testo $205 \mathrm{pH}$ meter (Testo Inc., Sparta, NJ, USA). The yolk was measured with an Ames micrometer (S-6428 model, Ames, Waltham, MA) to determine its height $(\mathrm{YH})(\mathrm{mm})$ and digital callipers (150 mm 6" Zaas Precision) were used to establish its diameter (YD) (mm). The yolk index (YI) was calculated as:

$$
Y I=Y H / Y D .
$$

Colour was measured with a Minolta CR-400 colorimeter (Konica Minolta, Inc., Osaka, Japan) to evaluate lightness $\left(L^{*}\right)(0=$ white, $100=$ black $)$, redness $\left(a^{*}\right)$ and yellowness $\left(b^{*}\right)$. Lipid oxidation was determined by a method that was adapted from Vyncke (1970). Ten gram aliquots of yolk were put into $50 \mathrm{ml}$ tubes, to which $25 \mathrm{ml}$ of trichloroacetic acid $7.5 \%$ solution was added. The samples were homogenized for 1.5 minutes with a Ultra Turrax MA 102 (Marconi Equipamentos Para Laboratórios Ltda., Piracicaba, São Paulo, Brazil) at $7000 \mathrm{rpm}$. The homogenate was filtered through qualitative filter paper, and duplicate $5 \mathrm{ml}$ aliquots of the filtered homogenate were transferred to test tubes. Five $\mathrm{ml} 0.02 \mathrm{M}$ thiobarbituric acid was added to each of the test tubes. Samples were placed in a water bath that was maintained at a temperature of $100 \stackrel{\circ}{\circ}$ for 40 minutes. Samples were analysed in a spectrophotometer (Shimadzu® UV-1800, Kyoto, Japan) with $532 \mathrm{~nm}$ wavelength, and the results were expressed as $\mathrm{mg}$ of malonaldehyde per $\mathrm{kg}$ of sample.

Data originated from two periods of storage and nine storage conditions with three replicates of 12 eggs each. Four eggs were randomly selected from each replicate to assess the response variables. Analysis of variance, appropriate to a $2 \times 9$ factorial arrangement of treatments, was done using the general linear model procedure of Statistical Analysis System (SAS Institute Inc. 2002-2003, Cary, North Carolina, USA). Means were compared with Tukey's test with significance set at $P<0.05$.

\section{Results and discussion}

The main factors that are involved in the deterioration in quality of stored eggs are the elevated temperature of the environment and dehydration. Improper storage may result in quality changes in dense albumen, an increase in the yolk diameter, enlargement of the air cell, and absorption of off-odours and offflavours (Tabidi, 2011). By simulating various storage conditions to which eggs could be subjected until the time of consumption, a significant interaction was revealed between storage time and types of storage 
affecting $\mathrm{HU}$ and $\mathrm{YI}$ (Table 1). All the fresh eggs had similar $\mathrm{HU}$ and $\mathrm{Yl}$. After 28 days of storage, eggs stored in $\mathrm{T} 1, \mathrm{~T} 3$, and $\mathrm{T} 5$ had greater $\mathrm{HU}$ than those stored in the other environments.

Table 1 Means for interaction between time in storage and type of storage affecting Haugh units and yolk index of eggs stored under different environmental conditions

\begin{tabular}{ccccc}
\hline & \multicolumn{2}{c}{ Haugh units } & \multicolumn{2}{c}{ Yolk index } \\
\cline { 2 - 5 } Conditions of storage & 0 days & 28 days & 0 days & 28 days \\
\hline T1 & $93.58^{\mathrm{Aa}}$ & $87.57^{\mathrm{Aa}}$ & $0.47^{\mathrm{Aa}}$ & $0.46^{\mathrm{Aa}}$ \\
T2 & $94.70^{\mathrm{Aa}}$ & $77.57^{\mathrm{Bb}}$ & $0.48^{\mathrm{Aa}}$ & $0.36^{\mathrm{Cb}}$ \\
T3 & $91.55^{\mathrm{Aa}}$ & $83.68^{\mathrm{Aa}}$ & $0.43^{\mathrm{Aa}}$ & $0.42^{\mathrm{Ba}}$ \\
T4 & $89.02^{\mathrm{Aa}}$ & $73.61^{\mathrm{Bcb}}$ & $0.49^{\mathrm{Aa}}$ & $0.34^{\mathrm{CDb}}$ \\
T5 & $86.23^{\mathrm{Aa}}$ & $75.78^{\mathrm{Ba}}$ & $0.46^{\mathrm{Aa}}$ & $0.33^{\mathrm{CDb}}$ \\
T6 & $92.05^{\mathrm{Aa}}$ & $71.91^{\mathrm{CDb}}$ & $0.47^{\mathrm{Aa}}$ & $0.31^{\mathrm{Deb}}$ \\
T7 & $90.91^{\mathrm{Aa}}$ & $70.79^{\mathrm{CDb}}$ & $0.45^{\mathrm{Aa}}$ & $0.28^{\mathrm{Eb}}$ \\
T8 & $90.37^{\mathrm{Aa}}$ & $66.46^{\mathrm{CDb}}$ & $0.46^{\mathrm{Aa}}$ & $0.27^{\mathrm{EFb}}$ \\
T9 & $95.69^{\mathrm{Aa}}$ & $65.14^{\mathrm{Db}}$ & $0.49^{\mathrm{Aa}}$ & $0.23^{\mathrm{Fb}}$
\end{tabular}

T1: storage for 28 days at $4^{\circ} \mathrm{C}, \mathrm{T} 2$ : storage for 28 days at $20^{\circ} \mathrm{C}$, T3: storage for 7 days at room temperature and for 21 days at $4{ }^{\circ} \mathrm{C}$, T4:: storage for 7 days at room temperature and for 21 days at $20^{\circ} \mathrm{C}$, T5: storage for 14 days at room temperature and for 14 days at $4{ }^{\circ} \mathrm{C}$, T6: storage for 14 days at room temperature and for 14 days at $20{ }^{\circ} \mathrm{C}$, T7: storage for 21 days at room temperature and 7 days at $4{ }^{\circ} \mathrm{C}$, T8: storage for 21 days at room temperature and 7 days at $20^{\circ} \mathrm{C}$, T9: storage at room temperature for 28 days

$\mathrm{A}, \mathrm{B}, \mathrm{C}, \mathrm{D}$ Means within a column followed by the same uppercase letter did not differ in Tukey's test at $P=0.05$

${ }^{\mathrm{a}, \mathrm{b}}$ Means within a trait and row followed by the same lowercase superscript letter did not differ in Tukey's test at $P=0.05$

Haugh units, which increase with albumin height and decrease with egg weight, are a standard measure of egg quality. Greater HU values represent better quality (Trinidad et al., 2007). Haugh units are influenced by genetic factors (strain), age of laying hen (Akyurek \& Okur, 2009), and environmental factors such as temperature and storage time (Samli et al., 2005; Akyurek \& Okur, 2009; Jin et al., 2011). During storage, egg quality decreases primarily because of loss of water and carbon dioxide $\left(\mathrm{CO}_{2}\right)$, with these losses being proportional to the temperature and humidity conditions (Souza et al., 1997; Akyurek \& Okur, 2009). Albumen height is at its maximum immediately after laying, and decreases with storage (Jin et al., 2011) because with ageing the proportion of liquid albumen increases at the expense of dense albumen (Leandro et al.i2005). On leaving the farm, fresh eggs have between 75 and 85 HUs on average (Coutts \& Wilson, 2007). To be of excellent quality for human consumption, the United States Department of Agriculture (USDA) recommends that eggs must have HUs greater than 72 (classified as "AA"), and good quality eggs must have HUs between 60 and 71 (classified as "A") (Menezes et al., 2012). Even after 28 days of storage, the eggs tested in this study could be considered good quality eggs.

Albumen buffering capacity is reduced In the presence of oxygen (Akyurek \& Okur, 2009). Carbonic acid $\left(\mathrm{H}_{2} \mathrm{CO}_{3}\right)$ in the egg breaks down to produce $\mathrm{H}_{2} \mathrm{O}$ and $\mathrm{CO}_{2}$, which are lost by evaporation through the shell (Gardner, 1995; Scatolini-Silva et al., 2010; Rocha et al., 2013). The result is that the flavour of the egg changes because of its increased alkalinity (Moreng \& Avens, 1990). Keeping eggs under constant refrigeration can preserve their internal quality and prolong their shelf life. However, when one considers the conditions of the Brazilian market, it seems that about $90 \%$ of eggs are commercialized in natura without refrigeration (Scatolini-Silva et al., 2010).

Only T1 and T3 preserved the height and diameter of egg yolks such that after 28 days of storage they were similar to the yolks of fresh eggs. Eggs in T9 had a reduced YI, which indicated poor yolk quality compared with all other storage conditions. The yolk flattening that becomes evident with increased time in storage is caused mainly by increased concentration of water by osmotic migration from the albumin through the vitelline membrane (Rocha et al., 2013), which is then weakened (Messens et al., 2005; Akyurek \& Okur, 2009; Jones et al., 2014) and can break easily (Tabidi, 2011). Researchers concluded that yolk height decreased about $10 \%$ with an increase of environmental temperature from $5{ }^{\circ} \mathrm{C}$ to $23{ }^{\circ} \mathrm{C}$, and there was only 
a slight reduction of yolk height with storage time (Keener et al., 2006). Thus, albumin height decreases at a more rapid rate than the yolk index.

Eggs stored for 28 days had greater $L^{*}$ (were darker), yolk $\mathrm{pH}$, and lipid oxidation than fresh eggs (Table 2). There was no effect of the type of storage on the lightness $\left(\mathrm{L}^{*}\right)$, redness $\left(\mathrm{a}^{*}\right)$, yolk $\mathrm{pH}$, and lipid oxidation. The increase in $L^{*}$ occurs because of the movement of water from albumen to the yolk that results from a difference in osmotic pressure (Moreng \& Avens, 1990; Rocha et al., 2013). Significant increases in the yolk $\mathrm{pH}$ were observed in studies of the effects of storage time, and not the influence of storage temperature (Samli et al., 2005; Akyurel \& Okur, 2009; Jin et al., 2011). In natura eggs are considered resistant to lipid oxidation, though the yolk lipids can undergo oxidation during storage (Cherian et al., 2007, Giampietro et al., 2008; Rocha et al., 2013). Carotenoids, resulting from feeding xanthophylls to laying hens that are deposited in the yolk, have an important antioxidant role and can protect yolk nutrients during storage (Rocha et al., 2013). The lipid oxidation (TBARS) results in this study were considered low, with no signs of rancidity, which can be perceived by sensory analysis and can cause problems to consumer health.

Table 2 Mean values of lightness $\left(\mathrm{L}^{*}\right)$, redness $\left(\mathrm{a}^{*}\right)$, yellowness $\left(\mathrm{b}^{*}\right)$, albumen $\mathrm{pH}$, yolk $\mathrm{pH}$, and lipid oxidation ( $\mathrm{mg}$ malonaldehyde/ $\mathrm{kg}$ ) of eggs stored for 28 days under different environmental conditions

\begin{tabular}{|c|c|c|c|c|c|c|}
\hline & $L^{*}$ & $a^{*}$ & $b^{*}$ & albumen $\mathrm{pH}$ & yolk pH & TBARS \\
\hline \multicolumn{7}{|c|}{ Storage periods (S) } \\
\hline 0 days & $61.45^{\mathrm{B}}$ & -5.13 & 37.94 & 8.35 & $6.09^{\mathrm{B}}$ & $0.177^{\mathrm{B}}$ \\
\hline 28 days & $64.45^{\mathrm{A}}$ & -4.82 & 48.27 & 9.53 & $6.34^{\mathrm{A}}$ & $0.215^{\mathrm{A}}$ \\
\hline \multicolumn{7}{|c|}{ Storage treatment $(\mathrm{T})$} \\
\hline T1 & 63.40 & -4.94 & 41.74 & 8.96 & 6.12 & 0.204 \\
\hline T2 & 62.85 & -4.51 & 43.28 & 8.92 & 6.19 & 0.208 \\
\hline T3 & 62.04 & -5.04 & 41.34 & 8.83 & 6.18 & 0.197 \\
\hline T4 & 63.71 & -5.01 & 42.18 & 9.07 & 6.11 & 0.190 \\
\hline T5 & 63.78 & -5.19 & 43.03 & 8.98 & 6.22 & 0.201 \\
\hline T6 & 63.79 & -5.97 & 44.93 & 9.02 & 6.29 & 0.184 \\
\hline T7 & 62.58 & -5.98 & 41.87 & 8.76 & 6.17 & 0.190 \\
\hline T8 & 62.51 & -5.49 & 43.40 & 8.87 & 6.39 & 0.195 \\
\hline T9 & 61.87 & -4.63 & 46.20 & 9.04 & 6.27 & 0.191 \\
\hline P-value (S) & $<0.0001$ & 0.1503 & $<0.0001$ & $<0.0001$ & $<0.0001$ & $<0.0001$ \\
\hline P-value $(T)$ & 0.6753 & 0.6196 & 0.2908 & 0.0381 & 0.3507 & 0.4858 \\
\hline P-value (SxT) & 0.1367 & 0.3814 & 0.0025 & 0.0019 & 0.8829 & 0.2390 \\
\hline CV (\%) & 3.84 & 18.10 & 8.94 & 2.01 & 3.59 & 5.97 \\
\hline
\end{tabular}

\footnotetext{
$A, B$ Storage periods differed significantly if the means have different superscript letters

TBARS: 2-thiobarbituric acid reactive substances; MDA, malonaldehyde; T1: storage for 28 days at $4{ }^{\circ} \mathrm{C}$; T2: storage for 28 days at $20^{\circ} \mathrm{C}$; T3: storage for 7 days at room temperature and for 21 days at $4{ }^{\circ} \mathrm{C}$; T4: storage for 7 days at room temperature and for 21 days at $20^{\circ} \mathrm{C}$; T5: storage for 14 days at room temperature and for 14 days at $4{ }^{\circ} \mathrm{C}$; T6: storage for 14 days at room temperature and for 14 days at $20^{\circ} \mathrm{C}$; T7: storage for 21 days at room temperature and 7 days at 4 ${ }^{\circ} \mathrm{C}$; T8: storage for 21 days at room temperature and 7 days at $20^{\circ} \mathrm{C}$; and T9: storage at room temperature for 28 days.
}

Significant interactions between storage period and type of storage were observed for albumen $\mathrm{pH}$ and yellowness $\left(b^{*}\right)$ (Table 3 ). Fresh eggs were similar in albumen $\mathrm{pH}$ and yellowness $\left(b^{*}\right)$ of yolk. After 28 days of storage, an increase in albumen $\mathrm{pH}$ was observed in eggs stored under all conditions, with the eggs in T9 having the greatest albumen $\mathrm{pH}$ value. Fresh eggs have a neutral $\mathrm{pH}$, and albumen that is transparent, consistent, dense, and consists of only a small fluid portion (Murakami et al. 1994). The albumin pH of recently laid eggs is approximately 7.6 (Coutts \& Wilson, 2007; Akyurek \& Okur, 2009) and increases to about 9.0 during storage (Akyurek \& Okur, 2009). The yolk pH of freshly laid eggs has been reported to be about 6.0 (Coutts \& Wilson, 2007), which is consistent with the current results (Table 2). Bakst andf Holm (2003) reported that during storage the yolk remains slightly acidic, with $\mathrm{pH}$ of approximately 6.5, which was slightly greater than the current observations. 
Table 3 Means for the interactions between storage period and type of storage that affected albumen $\mathrm{pH}$ and yellowness $\left(b^{*}\right)$ of eggs stored for 28 days under different environmental conditions

\begin{tabular}{ccccc}
\hline & \multicolumn{2}{c}{ Albumen $\mathrm{pH}$} & \multicolumn{2}{c}{$\mathrm{b}^{*}$ (yellowness) } \\
\cline { 2 - 5 } Conditions of storage $^{1}$ & 0 days & 28 days & 0 days & 28 days \\
\cline { 2 - 5 } T1 & $8.53^{\mathrm{Ab}}$ & $9.40^{\mathrm{Ba}}$ & $41.46^{\mathrm{Aa}}$ & $42.02^{\mathrm{Da}}$ \\
T2 & $8.22^{\mathrm{Ab}}$ & $9.63^{\mathrm{ABa}}$ & $38.57^{\mathrm{Aa}}$ & $47.99^{\mathrm{BCDa}}$ \\
T3 & $8.19^{\mathrm{Ab}}$ & $9.47^{\mathrm{ABa}}$ & $38.85^{\mathrm{Aa}}$ & $43.84^{\mathrm{CDa}}$ \\
T4 & $8.59^{\mathrm{Ab}}$ & $9.57^{\mathrm{ABa}}$ & $35.94^{\mathrm{Ab}}$ & $48.43^{\mathrm{BCa}}$ \\
T5 & $8.59^{\mathrm{Ab}}$ & $9.37^{\mathrm{Ba}}$ & $37.40^{\mathrm{Aa}}$ & $48.66^{\mathrm{BCa}}$ \\
T6 & $8.46^{\mathrm{Ab}}$ & $9.58^{\mathrm{ABa}}$ & $38.87^{\mathrm{Ab}}$ & $50.99^{\mathrm{Aba}}$ \\
T7 & $8.12^{\mathrm{Ab}}$ & $9.41^{\mathrm{Ba}}$ & $36.76^{\mathrm{Aa}}$ & $46.97^{\mathrm{BCDa}}$ \\
T8 & $8.14^{\mathrm{Ab}}$ & $9.60^{\mathrm{ABa}}$ & $36.29^{\mathrm{Ab}}$ & $50.50^{\mathrm{Aba}}$ \\
T9 & $8.35^{\mathrm{Ab}}$ & $9.79^{\mathrm{Aa}}$ & $37.35^{\mathrm{Ab}}$ & $55.04^{\mathrm{Aa}}$
\end{tabular}

T1: storage for 28 days at $4^{\circ} \mathrm{C}, \mathrm{T} 2$ : storage for 28 days at $20^{\circ} \mathrm{C}$, T3: storage for 7 days at room temperature and for 21 days at $4{ }^{\circ} \mathrm{C}$, T4:: storage for 7 days at room temperature and for 21 days at $20^{\circ} \mathrm{C}$, T5: storage for 14 days at room temperature and for 14 days at $4{ }^{\circ} \mathrm{C}$, T6: storage for 14 days at room temperature and for 14 days at $20{ }^{\circ} \mathrm{C}$, T7: storage for 21 days at room temperature and 7 days at $4{ }^{\circ} \mathrm{C}$, T8: storage for 21 days at room temperature and 7 days at $20^{\circ} \mathrm{C}$, T9: storage at room temperature for 28 days

$A, B, C, D$ Means within a column followed by the same uppercase letter did not differ by Tukey's test at $P=0.05$

${ }^{\mathrm{a}, \mathrm{b}}$ Means within a trait and row followed by the same lowercase superscript did not differ by Tukey's test at $P=0.05$

The increase in albumen $\mathrm{pH}$ during storage is unavoidable because of $\mathrm{CO}_{2}$ and water losses through the eggshell pores (Feddern et al., 2017). Most of the changes in the egg quality are related to humidity and these $\mathrm{CO}_{2}$ losses (Jin et al., 2011). The pH increase is related to the deterioration of the dense albumen (reduced $\mathrm{HU}$ ), which becomes progressively liquefied and diluted, becoming liquid albumen, which occurs because of the changes in the ovomucin-lysozyme complex from the $\mathrm{pH}$ increase over time (Tabidi, 2011). When they evaluated the effects of temperature and storage time on the quality of eggs from laying hens at peak production, Jin et al. (2011) observed a rapid increase in albumen alkalinity, regardless of storage temperature, with most of the increase occurring during the first five days of storage. The albumen $\mathrm{pH}$ rises rapidly in the first three days of storage and then has little change, whereas the yolk pH rises slowly during prolonged storage (Linden \& Lorient, 1996; Barancelli et al., 2012).

The impermeability of the vitelline membrane is important for food safety (Messens et al., 2005). It decreases with storage time, which can allow nutrients in the yolk to become available for any microorganisms that are present in albumen (Kirunda \& McKee, 2000; Keener et al., 2006; Akyurek \& Okur, 2009). However, with increasing albumen $\mathrm{pH}$, the environment within the egg becomes unfavourable to the development of pathogens such as Salmonella (Humphrey, 1994), which require pH between 6.0 and 7.5 for multiplication (Banwarth, 1989). Eggs also contain enzymes that impede the growth of bacteria (Oliviera \& Silva, 2000).

The yellow colour of the yolk is related directly to a diet that is rich in carotenoid pigments, usually from xanthophylls such as corn (Rocha et al., 2013). In this study, there was greater yellowness of the yolks from eggs that were subjected to T4, T6, T8, and T9, compared with the colour of fresh egg yolks, perhaps because of some increase in the products of oxidation. Being unsaturated, carotenoids are subject to oxidation in the presence of light, heat and pro-oxidant compounds, which can result in discoloration of the yolk (Ribeiro \& Seravalli, 2004; Melendez-Martinez et al., 2004). Jin et al. (2011) observed a reduction in yolk colour with storage time. The authors attributed this to the possible dilution of the yolk pigments caused by the breakdown of the vitelline membrane. In contrast, Giampietro-Ganeco et al. (2012) suggested that the reduction of internal quality in commercial eggs causes liquid waste to migrate from the yolk to the albumen, resulting in an increased concentration of the carotenoid pigments and thus a more intense yellow colour.

\section{Conclusion}

Egg quality is influenced by room temperature and storage time. Eggs should be stored under refrigeration as this maintains internal quality and mitigates the negative effects of previous conditions. The transportation of eggs for later marketing should be carried out in a refrigerated vehicle to preserve product 
quality. More studies are needed to verify the extent of lipid oxidation and free radical production in stored eggs.

\section{Acknowledgments}

The authors thank the Coordination of Superior Level Staff Improvement (CAPES) programme and the Agribusiness Technology Agency of São Paulo, Institute of Animal Science (APTA)

\section{Authors' Contributions}

ASR and BH designed the study, and all of the authors collaborated in the collection of data. ASR performed the statistical analysis and wrote the article. All authors read the final article and approved its contents.

\section{Conflict of interest declaration}

The authors declare that they have no conflict of interest relative to this work.

\section{References}

ABPA. Brazilian Association of Animal Protein, 2020. Annual report. São Paulo, Brazil.

Akyurek, H. \& Okur, A.A., 2009. Effect of storage time, temperature and hen age on egg quality in free-range layer hens. J. Anim. Vet. Adv. 8, 1953-1958.-https://www.researchgate.net/publication/289700674_Effect_of_Storage_Time_ Temperature_and_Hen_Age_on_Egg_Quality_in_Free-Range_Layer_Hens

Banwarth, G.J., 1989. Basic food microbiology. 2nd ed. $\bar{V}$ an Nostrand Rheinhold, New York.

Barancelli, G.V., Prado, J.G.P.M. \& Porto, E., 2012. Salmonella em ovos: relação entre produção e consumo seguro. Segurança Alimentar e Nutricional 19, 73-82. DOI: 10.20396/san.v19i2.8634612. (In Portuguese).

Bakst, M.R., Holm, L., 2003. Impact of egg storage on carbonic anhydrase activity during early embryogenesis in turkey. Poult. Sci. 82, 1193-1197. DOI: 10.1093/ps/82.7.1193

BRASIL, 2009. Resolução $n^{\circ}-35$, de 17 de junho de 2009. Dispõe sobre a obrigatoriedade de instruções de conservação e consumo na rotulagem de ovos e dá outras providências. Diário Oficial, Brasília, p.47, seção 1 de 18.06.2009.

Card, L.E. \& Nesheim, M.C., 1978. Produción avícola. Zaragoza: Editoral Acribia.(In Spanish).

Cherian, G., Traber, M.G., Goeger, M.P. \& Leonard, S.W., 2007. Conjugated linoleic acid and fish oil in laying hen diets: Effects on egg fatty acids, thiobarbituric acid reactive substances, and tocopherols during storage. Poult. Sci. 86, 953-958. DOI: $10.1093 / \mathrm{ps} / 86.5 .953$

Coutts, J.A. \& Wilson, G.C., 2007. Optimum egg quality - A practical approach. 5m Enterprises, Sheffield, UK. 66 pp.

Feddern, V., De Prá, M.C., Mores, R., Nicoloso, R.S., Coldebella, A. \& Abreu, P.G. 2017. Egg quality assessment at different storage conditions, seasons and laying hen strains. Ciênc. agrotec. 41, 322-333. Doi: 10.1590/141370542017413002317.

Gardner, F.A., 1995. Fatores de qualidade do ovo desde a produção até o consumo. In: Fundação Cargil. Tópicos avícolas. São Paulo; 1-9. (In Portuguese)

Giampietro, A., A., Scatolini, A.M., Boiago, M.M., Coró, D.M.O., Souza, H.B.A., de Souza, P.A., de Azevedo Lima, T.M. \& Pizzolante, C.C., 2008. Estudo da metodologia de TBARS em ovos. Rev. Avisite 13, 18-18. (In Portuguese)

Giampietro-Ganeco, A., Scatollini-Silva, AM, Borba, H., Boiago, M.M., Lima, T.M.A. \& Souza, P.A., 2012. Estudo comparativo das características qualitativas de ovos armazenados em refrigeradores domésticos. Ars Veterinaria, Jaboticabal, SP, 28(2),100-104 (In Portuguese).

Haugh, R.R., 1937. The Haugh unit for measuring egg quality. US Egg Poult. Mag. 4, 552-555.

Humphrey, T.J., 1994. Contamination of egg shell and contents with Salmonella enteritidis: A review. International Journal of Food Microbiology 21, 31-40.

lannotti, L.L., Lutter, C.K., Bunn, D.A. \& Stewart, C.P., 2014. Eggs: The uncracked potential for improving maternal and young child nutrition among the world's poor. Nutrition Reviews 72(6). Doi: 10.1111/nure.12107

Jin, Y.H., Lee, K.T., Lee, W.I. \& Han, Y.K., 2011. Effects of storage temperature and time on the quality of eggs from laying hens at peak production. Asian-Aust. J. Anim. Sci. 24, 279-284. DOI: 10.5713/ajas.2011.10210

Jones, D.R., Karcher, D.M. \& Abdo, Z., 2014. Effect of a commercial housing system on egg quality during extended storage. Poult. Sci. 93, 1282-1288. DOI: 10.3382/ps.2013-03631

Kenner, K.M., Mcavoy, K.C., Foegeding, J.B., Curtis, P.A., Anderson, K.E. \& Osborne, J.A., 2006. Effect of testing temperature on internal egg quality measurements. Poult. Sci. 85, 550-555. DOI: 10.1093/ps/85.3.550

Kirunda, D.F.K. \& Mckee, S.R., 2000. Relating quality characteristics of aged eggs and fresh eggs to vitelline membrane strength as determined by a texture analyzer. Poult. Sci. 79, 1189-1193. DOI: 10.1093/ps/79.8.1189

Leandro, N.S.M., Deus, H.A.B., Stringhin, J.H., Café, A.B., Andrade, M.A. \& Carvalho, F.B., 2005. Aspectos de qualidade interna e externa de ovos comercializados em diferentes estabelecimentos na região de Goiânia. Cienc Anim Bras 6, 71-78. (In Portuguese)

Linden, G., Lorient, D., 1996. Bioquímica Agroindustrial. Revalorización Alimentaria de la producción agrícola. Zaragoza: Acribia. (In Spanish)

Meléndez-Martinez, A.J., Vicario, I.M. \& Heredioa, F.J., 2004. Estabilidad de los pigmentos carotenoides em los alimentos. Archivos latino-americanos de Nutricíon, Caracas 54, 2,209-215. (In Spanish)

Menezes, P.C., Lima, E.R., Medeiros, J.P., Oliveira, W.N.K. \& Evêncio-Neto, J., 2012. Egg quality of laying hens in different conditions of storage, ages and housing densities. R. Bras. Zootec., 41, 2064-2069. 
Messens, W., Grijspeerdt, K. \& Herman, L., 2005. Eggshell penetration by Salmonella: A review. World Poult. Sci. 61, 71-85. DOI: 10.1080/00071660500395582

Morais, C.F.A., 1995. Qualidade interna de ovos comercializados em uma rede de distribuição em Uberlândia/MG. Master thesis on animal production, Escola de Medicina Veterinária, Universidade Federal de Minas Gerais, Belo Horizonte. $63 \mathrm{pp}$.

Moreng, R.E. \& Avens, J.S., 1990. Cien e prod aves. Roca, São Paulo. Pp 227-249.

Murakami, A.E., Barriviera, V.A., Scapinello, C., Barbosa, M.J. \& Valério, S.R., 1994. Efeito da temperatura e do período de armazenamento sobre a qualidade interna do ovo de codorna japonesa (Coturnix coturnix japonica) para consumo humano. Rev Unimar 16, 13-25. (In Portuguese)

Oliveira, D.D. \& Silva, E.M., 2000. Salmonela em ovos comerciais: ocorrência, condições de armazenamento e desinfecção da casca. Arq Bras Med Vet Zootec 52, 655-661. DOI: 10.1590/S0102-09352000000600017. (In Portuguese)

Ribeiro, E.P. \& Seravalli, E.A.G., 2004. Química de alimentos. Instituto Mauá de Tecnologia. Editora Edgard Blücher Ltda, 3rd edition. São Paulo. Pages 155-157. (In Portuguese)

Rocha, J.S.R., Barbosa, V.M., Lara, L.J.C., Baião, N.C., Cançado, S.V., Lana, A.M.Q., Pompeu, M.A., Vasconcelos, R.J.C., Machado, A.L.C., Miranda, D.J.A., Fernandes, M.S.N. \& Mendes, P.M.M., 2013. The effect of storage and dietary canthaxanthin on fertile egg quality and embryonic development. Arq. Bras. Med. Vet. Zootec. 65, 792800. DOI: $10.1590 / S 0102-09352013000300027$

Samli, H.E. \& Agna, A., Senkoylu, 2005. Effects of storage time and temperature on egg quality in old laying hens. J. Appl. Poult. Res. 14, 548-533. DOI: doi.org/10.1093/japr/14.3.548

Scatolini-Silva, A.M., 2010. Características físicas e químicas, sensoriais e microbiológicas de ovos armazenados em diferentes condições de embalagens sob temperatura ambiente. PhD thesis in Animal Science. 96 pp. Faculdade de Ciências Agrárias e Veterinárias, Universidade Estadual Paulista. (In Portuguese).

Souza, P.A., Souza, H.B.A., Barbosa, J.C., Gardini, C.H.C. \& Neves, M.D., 1997. Effect of laying hens age on the egg quality maintained at room temperature. Cien Tecnol Aliment 17 (1), 49-52. (In Portuguese, English abstract).

Tabini, M.H., 2011. Impact of storage period and quality on composition of table egg. Advances in Environmental Biology $5,856-861$.

Trindade, J.L., Nascimento, J.W.B. \& Furtado, D.A.I., 2007. Qualidade do ovo de galinhas poedeiras criadas em galpões no semi-árido paraibano. Rev. Bras. Eng. Agríc. Ambient 11, 652-657. (In Portuguese). DOI: 10.1590/S141543662007000600015

Vynche, B.W., 1970. Direct determination of the thiobarbituric acid value in trichloroacetic acid extracts of fish as a measure of oxidative rancidity. Fette Seifen Anstrichm 72 n.12, 1084-1087. DOI: 10.1002/lipi.19700721218

Yilmaz, A.A. \& Bozkurt, Z., 2009. Effects of hen age, storage period and stretch film packaging on internal and external quality traits of table eggs. Lucrări ştiinţifice Zootehnie şi Biotehnologii, 42 (2). (In Romanian). DOI: $10.15193 /$ zntj/2016/105/114 